\title{
Intermediate Technology for Food Security and Sustainable Development in the Central Rain Lands of Sudan: The Need and Justification
}

\author{
Abdel Raouf Suleiman Bello \\ Department of Agricultural Extension and Rural Society \\ College of Food and Agriculture Sciences \\ King Saud University, Kingdom of Saudi Arabia, \\ and \\ Department of Agricultural Extension and Rural Development, \\ Faculty of Agriculture, University of Khartoum, Sudan
}

\begin{abstract}
Animal traction technology has been introduced by various rural development projects in different areas of the Sudan, as an alternative to the purely traditional, and modern agricultural technologies. The idea is aimed at introducing simple, efficient, and appropriate agricultural techniques to increase agricultural productivity and the cultivated area, as well as to promote off-farm activities in the rural areas. It is clearly noticed that the rural development projects based on animal traction in Western Sudan has achieved considerable socio-economic and environmental impacts there. These consequences range from upgrading of traditional agricultural hand tools, increasing the cultivated area to productivity per feddan, improving of local skills, and provision of jobs for some marginal groups such as black smiths, landless groups, and others.
\end{abstract}

Key words: Intermediate technology; animal traction; rain lands, Sudan.

\section{INTRODUCTION}

Sudan is a very large agricultural and pastoral country in Africa with total area is estimated to 2,505,813 sq. km and contrasting sharp differences in all its characteristics (Ali, 2012). From north to south, the desert semi-desert with ephemeral grasses and xerophytes scattered shrubs to short grass savannah, through long grass savannah to tropical forest with evergreen trees and tall and very thick canopy of grasses. The country total population of well over 33 million, out of which $51 \%$ live in rural areas. Agriculture is the dominant sector in the Sudanese economy. It contributes about 31.6\% to the Gross Domestic Product (GDP), and about $9 \%$ of nonpetroleum exports, and provides the raw materials for agro-industries and employment for over $50.23 \%$ of the labor force (Bello, et al. 2016). According to the WFP (2015), household food security in Sudan is strongly linked to the performance of the agricultural sector of the economy. Directly, the agricultural sector provides food production for domestic consumption at household level and wage labor opportunities on farms. However, as indicated by the WFP (2015) the sector account for 27 percent of the active labor force. Indirectly, the level of agricultural production influences the price of food, which helps determine household economic access, as most households rely on markets as their main food source. The country agricultural sector comprises five sub-sectors: modern (mechanized) irrigated schemes, traditional irrigated, mechanized rain-fed, traditional rain-fed and livestock husbandry/pastoralism. Each of these sub-sectors produces food and cash crops for both local consumption and export. The traditional rain fed subsector is responsible for the production of most of the sorghum, millet and groundnut (Mahgoub, 2014). According to by Suleiman et al 
(2008) constraints limiting production in traditional rain-fed sub-sector sector are: a- Low productivity resulting from use of traditional technology; b- Lack of rural saving and credit institutions; c- Marketing bottlenecks; d- Lack of research and extension services; e- Poor infrastructure; f- Inadequate safe water; g- Weed and pest infestation; h- Over-cultivation and shifting exhausted far m plots, passing-by animals, and i- Seasonal and sharp variations of rainfall and complete failure in some years (uncertainty).

Rain-fed agriculture produces much of the food consumed globally, precisely by poor communities in developing countries. This sector accounts for more than $95 \%$ of farmed land in sub-Saharan Africa; $90 \%$ in Latin America; 75\% in the Near East and North Africa; 65\% in East Asia; and $60 \%$ in South Asia. Various factors can cause agricultural productivity to increase or decrease in this sector. Such factors include: a-Weather, b-capacity of a given farm, c- pests, d- available and e-market supply and demand (http://www.agrivi.com/factors-thataffectagricultural- productivity/2016).

The central rain lands of the Sudan, referred to in this study; embrace the area situated between the latitudes 9-15 degree North, and the longitudes 22-33 degree East within the boundaries of the Republic of the Sudan. This region represents about one third of the 2.5 millions square kilometers of the total area of the country and over half of the 85.46 million acres of its total arable land. Moreover, about half of the total populations of Sudan live in this area. About 80-85 percent of the population is engaged in crop or livestock production. The main crops that are grown in this region are food crops (sorghum and millet), and cash crops (sesame, groundnuts, hibiscus, watermelon and small areas of beans as well as gum Arabic. It is worth mentioning that the cultivated varieties are long maturing varieties. Agricultural rotation with fallow period (i.e. shifting cultivation) is practiced for different purposes and in different manner. This farming system traditionally consists of about 5 years of cropping. In some areas, especially in the northern parts of the region, the follow period extents to about fifteen to twenty years for regeneration of Acacia senegal for Gum Arabic production. It is believed that the follow period rests the soil and the regenerated Acacia senegal protects it from being blown off and improve its fertility, hence further period of cropping can be supported again (El Siddig, 2003).

Ecologically, the entire area is included in the low rainfall poor land savannah on sandy goz in the northern parts of the region to gardud soils (mixture of clay and sandy soils in the central parts) to heavy clay soils in the southern parts. Thus, and concerning the cropping pattern in the area, the traditional farmers decide on what to produce, and methods to be used to suite the sets of objectives, and interest as well to suit their soil type (i.e. goz), gardud and/or clay soils. In addition to the Acacia Senegal, traditional farming system practiced on privately owned land, two types of land- leased are noticed in the region as follows:

i- Traditional Acquisitions, which include: a- Land ownership acquired through common ancient residence, b- Clearing land according to customary land use pattern in the area, cAliens who migrated and were granted the right to cultivate the land by villages, sheikhs ; and d- Acquisition through plantation of trees on plots or wadi beds or tapping hashab (Acacia Senegal), and ii- Formal land Records: The few cases of land registration in the region mainly for mechanized rain fed agriculture, which limited only to the gardud (mixed lay and sandy) and clay soils in southern parts, and small plots in wadi beds (valleys) for horticultural products. 
Administratively, this region covers the area of former Darfur and Kordofan states, which collectively form the territory of Western Sudan. It was highly affected by the 1980s and the late 1990s drought that resulted in serious damage of agriculture, livestock, and natural resources. As a result thousands of rural people were compelled to migrate to the urban centers and to areas of large plantations in central Sudan to work as wage labourers to maintain their food. Thus there is urgent need to do some efforts for agricultural development to convince the migrants to return home and to enable them to exploit the available resources to maintain their living on sustainable. To meet these objective considerable efforts from the national government, NGOs and UNs agencies (based on intermediate technology) were carried there to cater with these problems. These include North Kordofan Special Program for Food Security, South Kordofan Rural Development Program (IFAD), North Kordofan Rural Development Program (IFAD), Jabal Mara Rural Development Project ( south and Western Darfur, Kabkabiya Small Holders Agricultural Development Project and others( Belal, 2015; Bello and Muneer, 2008). Despite this fact some areas in Kordofan and Darfur States are still suffering from natural disasters and facing food shortage, continuing rural-urban migration especially among the young males, leaving behind the females, children and the aged people practice traditional agriculture and animal production to maintain their livelihood. Factors limiting agriculture in this region as indicated by Bello (2014), Suleiman et al (2008) and Muneer (1998) are as follows: i- Low productivity resulting from rational technology; ii- Lack of rural savings and credit; institutions; iii- Marketing bottlenecks; iv- Lack of research and extension services; v- Poor infrastructure; vi- In adequate safe water; vii- Weed and pest infestation; viii- Drought; ix- Ongoing civil wars; $x$ - Over cultivation and shifting exhausted farm plots, passing by animals; and vi- Seasonal and sharp variations of rainfall and complete failure in some years(uncertainty).

Moreover, the ongoing conflicts in Darfur and Nuba Mountains (South Kordofan) sates are major damaging hazard for livelihoods and basic food security in this area. Continuous fighting over the last decade of years and its attendant consequences have continually undermined access to markets and migration, and denied households the opportunity to effectively address structural seasonal food deficits which typically occur between April and August. In this regards Bello (2014) commented that resulted in loss of lives of innocent persons, damage to the properties, vanishing of social services and degradation of natural resources.

Natural hazards and droughts that stem from the lack of seasonal rains do contribute to poor harvests, livestock death and food insecurity in many parts of the country. Poor harvest, poverty, failed rains and pasture shortages, together with an unstable social and political environment that can be traced to civil wars and conflict, as well as the absence of good governance have combined and contributed to underdevelopment, serious food crisis and food insecurity in the country (UNDP, 2012).

\section{SUDAN ECONOMY}

Agriculture is the backbone of the national economy in the Sudan as it contributes $40 \%$ of the gross domestic product (GDP) and contributes principally in the generation of foreign currency for the country. The agricultural sector creates employment opportunities directly and indirectly for $80 \%$ of the population in Sudan. The country has wide and diversified renewable agricultural resource-base including climate, biodiversity, soils and water. Sudan multivariate ecological zones provide for different farming systems, crops, livestock, fisheries, forestry production and other economic activities. Only 18 million hectares of its estimated arable land 
(86 million hectares) are now utilized. River Nile and tributaries, rainfall, seasonal streams and underground water are the major sources of water in the main producing areas where the irrigated, mechanized and traditional (subsistence) rain fed agriculture are practiced. The agricultural sector has the potential to be an additional engine of growth to the oil sector that would allow the country to diversify its economy to achieve transformational development and reduce poverty and food insecurity (UNDP, 2012). The heterogeneous nature of the country resulted in sharp variations in the production and consumption of food and other crops. The relatively cold weather in the four winter mouths in the north allows the production of the short day crops such as wheat legumes, citrus fruits and drought-tolerant date palm trees. A range of food and industrial crops are grown in eastern central and western Sudan such as sorghum, millet, sugar care, cotton, gum Arabic, sesame and groundnuts using irrigation and the direct rains. Sudan has about 135 million heads of animals. Most of the livestock are raised mainly by nomadic tribes in the plains from the Red Sea coast through the central rain-belt in the clay plains in the east and centre through the sandy areas in the west and north-western parts of the country. In the north, very few animals but of good quality are raised in the houses or orchards for family milk and meat and to sell when and if need for money arises. Some oxen, camel and donkeys are use as draught animals for water lifting and for transportation in the north and western Sudan. Livestock production in Sudan occurs mainly under the traditional rain fed sector, which depends on the natural pastures of Kordofan, Darfur, and White Nile, Blue Nile and Gezira and other regions. This traditional sector is the main source of supply of livestock (live animal or red meat) for the domestic and foreign markets (Suleiman et al., 2008). The traditional sector raises livestock in open pastures under transhumant nomadic system following the rains and grazing pastures across the country. The intensity of natural pastures increases from northern to southern parts of the Sudan. In summers, animals graze pastures in the north and move southwards to tap the rich pastures of the south. Over the years, the overgrazed pasture changed grass species and the quality of pasture and deteriorates giving way to poor grasses. The movement of livestock over long distances produces livestock with lean muscular meat. The average weight of a typical head of cattle approaches 125 kilograms, whereas the average weight under controlled system of feeding approaches 200 kilograms per head. Similarly, the average weight of a sheep under open pasture system is about 28 kilograms while under controlled fattening system it is about 48 kilograms. Furthermore, this traditional system results in low fertility with low birth rates thus increasing the livestock population at a slow growth rate. According to Suleiman et al. (2008) the livestock local markets suffered inter alia from: i- Lack of adequate market information about livestock prices due to secrecy in pricing system and dependence on buyers' subjectivity estimation; ii- Limited practices in marketing auction system; iii- Duplication in livestock fees leading to increased animal prices; iv- Non-compliance in livestock-trade with quality and standards of importing partners; iv- Scarcity of livestock supply in the local markets in face of increased demand for exports; $v$ - Sanitation measures by certain importing partners led to decrease in demand or ban imports of livestock in certain years (due to suspect of infectious diseases: ban of livestock and meat imports into Saudi Arabia in 2000), and vi- Seasonality, as livestock moves into remote areas according to rains and pastures, and therefore reduces the marketable supply.

\section{FOOD SECURITY}

Food Security is a term that evolved in the mid 1980s after realizing the non-applicability of the food self sufficiency approach of the 1970s. The concept of food security explicitly and/or implicitly advocate for both supply and access to food. Access to food could be attained through different forms such as availability in the market in affordable prices (market access) and /or 
increasing income through employment opportunities generation with improving purchasing power of consumers. There are more than twenty definitions about food security and they all rotate around benefiting from food for healthy and active life. The World Bank and FAO had almost similar definitions for food security. As for the World Bank (1986) the definition of food security is: "Access by all people at all times to sufficient food for an active healthy life". This definition indicates that to achieve this goal three conditions have to be met namely: Ensuring stability of food supply, ensuring access to food, and ensuring adequacy of food supply. The FAO-World Food Summit-Plan of Action - in 1996 - defined food security as "a situation in which all households have both physical and economic access to adequate food for all members and where households are not at a risk of such access" (FAO, 1996:2).This definition indicates three dimensions: Availability of sufficient food, affordability of sufficient food, and stability of sufficient food.

\section{Food Security in Sudan}

Households throughout Sudan have traditionally survived on a mixture of agriculture and pastoralism, with sedentary agriculture more common in the Greenbelt region of Southern parts and nomadic pastoralism more common in the arid climate of northern parts of the country. In recent years reliance on these traditional livelihood sources has weakened somewhat, challenged by natural disasters, expansion of rain fed mechanized agriculture, continuing conflict and insecurity and rapid urbanization. Household food security status in Sudan is determined by the combination of aggregate food availability, household food access and utilization based on FAO (1996) definition as illustrated below:

\section{Availability of food}

In Sudan, given climate extremes and insecurity, food availability is a crucial component of household food security status. The majority of agricultural output in Sudan is from small subsistence farmers, crop production in the north appears increasingly dependent on larger mechanized and irrigated farms. Consequently, household crop production is more common in all parts of the country. The primary staple crops in Sudan as indicated before are sorghum and millet, as both grow well in arid climates.

\section{Access to food}

Access to enough food to meet dietary energy needs for the household is also a significant obstacle in parts of Sudan, determined primarily by land productivity, security and market access. In the drier often desert conditions areas, households purchase close to 90 percent of their food. In the States (e.g. South Darfur, South Kordofan, Blue Nile State) in southern parts of the Sudan, households generally live a subsistence lifestyle in which 40 percent of food comes from own production and 10 percent from hunting, gathering and fishing. While food purchase remains an important source of food (with 39 percent of food accessed in this way), limited market access and security problems force most households to rely on own production.

\section{Utilization}

Food security can only be achieved if all household members have access to safe and nutritious food and if their health status allows them to adequately absorb the nutrients ingested. The best proxy indicators of utilization as indicated by are child health and nutritional status. The nutritional situation of children in Sudan is characterized by unusually high wasting (or global acute malnutrition- GAM) prevalence, often above the 15 percent in the country. In Sudan, this 
is hypothesized to be due to the interaction of poverty, poor access to water and sanitation, and high disease prevalence (diarrhea, malaria, etc.).

\section{SUSTAINABLE DEVELOPMENT}

The concept of sustainable development approach (SDA) has emerged and received an increasing interest during the last two decades, in the international agencies as well as in NGOs and the national governments programs. It focuses mainly on the attainment of the needs of all people (where they are) and to improve their capabilities to achieve their objectives for a better life and to maximize their interest without depriving the future generations. Thus, the approach aims at economically efficient, socially viable and ecologically sound resource use. It therefore, focuses on the urgency of managing natural resources. Thus creating some sustainable measures of protecting, conserving and developing natural resources to maximize benefits from using these resources without causing damage to their existence, reproduction (renewable) and use by all people presently and in the future (i.e. to guarantee their sustainability).

\section{Concepts and arguments}

\section{ANIMAL TRACTION TECHNOLOGY}

The term appropriate (AT) and Intermediate technology (IT) are used interchangeable in the literature to refer to the type of technology compatible with the conditions of the developing countries. The exact difference between the two terms is still some what inclusive theoretical debates and there is no clear cut distinction of what constitutes an appropriate and/ or intermediate. As indicated in the literature, the term AT is considered to refer to low-cost intermediate technologies, which are developed, used or imported by the developing countries and which need their resource endowments of these countries. On the other hand to some writers IT is a relative term: a technology that stands between what is known, the traditional technology and the modern technology. Thus animal traction implements (i.e. the hoe, the seeder and planter) falling half-way between the traditional hoe (i.e. hashasha, torya and maloda) and the tractor. Moreover to some economists IT is taken to be the low- cost technology in terms of low- cost per place, low capital cost per unit output, and low capital cost per machine (Smillie, 1991). Thus the terms AT and IT are synonymous, because IT, if it is going to be practical for development purposes, it has to be an appropriate technology.

Furthermore, as indicated in Bello, (1998), there are some prerequisites for the success of IT including the following: i- Workplaces should be established where people live; ii- It should be cheap so as to be produced in large numbers; iii- It require simple production methods, and low sustainable skill, and iv- Production depends on local materials and mainly for local use.

The importance and use of draught animals as intermediate technology in the developing countries cannot be underestimated, because of their low cost, availability and capacity to increase light land cultivation. They play an important role especially in the livelihood of the resource poor rural farmers who cannot afford the high cost of modern farming machineries (Sanni et al., 2004). Since time immemorial, animals have supplemented human limbs by providing power to till and cultivate the soil and to transport farm produce, even to distant towns (H. Kubkomawa, et al 2011). According to Houssou et al. (2013) animal traction technology is a significant component of agricultural mechanization. Draft animals are a major source of farm power in the drier rain-fed farms of sub-Saharan Africa, especially among smallscale farmers (Ouattara et al., 2005). Animal traction can serve as an intermediate and transitional technology between hand hoe and cutlass-based agriculture and tractor-based 
mechanized agriculture. Animal traction can ease the power bottlenecks and complement the use of tractors and other farm power sources (Houssou et al., 2013).

Moreover, as indicated by Belal et al (2015) animal power is a renewable energy source that is particularly suited to family-level farming and to local transport. Animal power is generally affordable and accessible to the small holder farmers, who are responsible for much of the world's food production. The availability of animal power allows women and men to increase their efficiency and reduce drudgery, compared with manual alternatives. The combination of timeliness and timesaving in field operations promotes the achievement of higher and more reliable crop yields. However, Animal power is generally affordable and accessible to the small holder farmers, who are responsible for much of the world's food production. Compared with manual alternatives, the use of animal power allows rural farming households to increase their efficiency and reduce their drudgery. The combination of timeliness and timesaving in field operations promotes the achievement of higher and more reliable crops yield (FAO, 2007). Moreover, Houssou et al. (2013) commented that just like a tractor, animal traction can contribute to improved agricultural production and food security in many sub-Saharan African countries where the technology is still relevant. He also indicated that addressing the constraints faced by users of draft animals is likely to create an environment conducive to the development of the technology. Research and policy are essential to upgrading and scaling up the use of animal traction technology. In Ghana, for example, to expand animal traction would require reviving abandoned training centers, assisting local blacksmiths and investing in research on animal traction. Likewise, reduction in labor requirements must be an integral part of improvements to animal traction technology in the country.

\section{Past Experience of Animal Traction in Western Sudan}

Various studies conducted on the experience of the rural development projects based on IT in western Sudan (i.e. The Nuba Mountains Rural Development Project, The Area Development Schemes and Jebel Marra Rural Development Project), concluded that they have achieved considerable socio- economic and environmental impact. These impacts range from upgrading of traditional agricultural hand tools, to increasing the cultivated area, and productivity per fedan, to improving local skills for some marginal groups (i.e. blacksmiths, landless groups and others). However it provides a vital means of transport for the local inhabitants.

The experience of the Nuba Mountains Rural Development Project (NMRDP) in South Kordofan State (1979- 1995), is considered one of the most successful attempts carried out in the country. According to Bello (1998), the project was planned and executed as an animal traction project to achieve the following objectives:1- To increase crop production in the traditional sector, through increasing the cropped area, improving yield per unit farm, technological level, and the capabilities of the traditional farmers; 2- Better utilization of livestock as source of power in agricultural operations, and production; 3- To increase farmers income, and to improve the standard of living of the rural communities at the project area; 4- To develop and encourage rural industries; 5- To increase gum Arabic production, and soil conservation and maintenance by intercropping Accacia Senegal.; 6- To reduce dependence costly imported machinery (i.e. tractors, fuel and spare parts), and 7- To encourage cooperative movements in the project area.

Characteristics and uses of the different implements adopted by the project are shown the table 1. 
Table 1: Implements Characteristics and Use

\begin{tabular}{|l|l|l|}
\hline \multicolumn{1}{|c|}{ Type } & \multicolumn{1}{c|}{ Characteristics } & \multicolumn{1}{c|}{ Use } \\
\hline Nuba hoe & $3-5$ tines & Land preparation and weeding \\
\hline Seeder & $1-2$ rows & Sowing \\
\hline Groundnuts lifter & Blade & Groundnuts lifting \\
\hline Oxen and donkeys carts & Axle + types & Transport \\
\hline Ridger & Blade & Ridges making \\
\hline
\end{tabular}

Source: Bello (1998)

According to Bello, (1998), the animal traction implements introduced by the project have resulted in considerable socio- economic and environmental impacts. These consequences range from upgrading of traditional agricultural hand tools, improving of agricultural practices, to increasing agricultural production, which resulted in sustained food base (i.e. food security), and surplus production for cash, which is reflected in the consumption, significant changes in the beneficiaries life style, as well as their savings and investment practices. However, the use of draft animals (i.e. oxen), as a source of power in agricultural operations especially among the Nuba who are traditional farmers (usually keep goats and sheep as livestock), and the Baggara Arab who are nomadic pastorals (the traditional cattle breeders in the Western Sudan) who usually keep cattle for social prestige, is considered a real social transformation in the project area. Moreover, there were impressive environmental impacts including maintaining and up-keeping of the soil fertility, due to the ridges use and other practices which resulted in better use of rainfall. This is reflected in improved crop yield and fodder production.

Figure1: Jabel Marra modified toolbar- Darfur

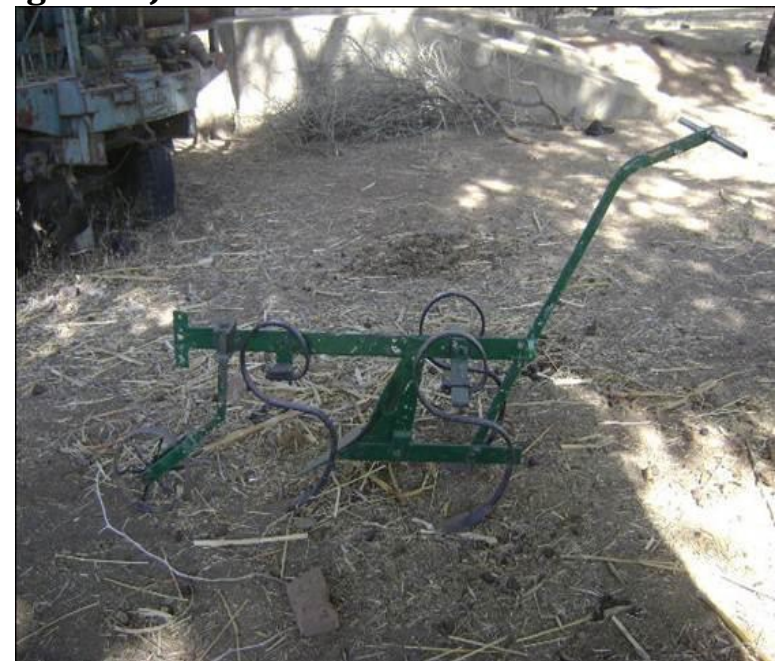




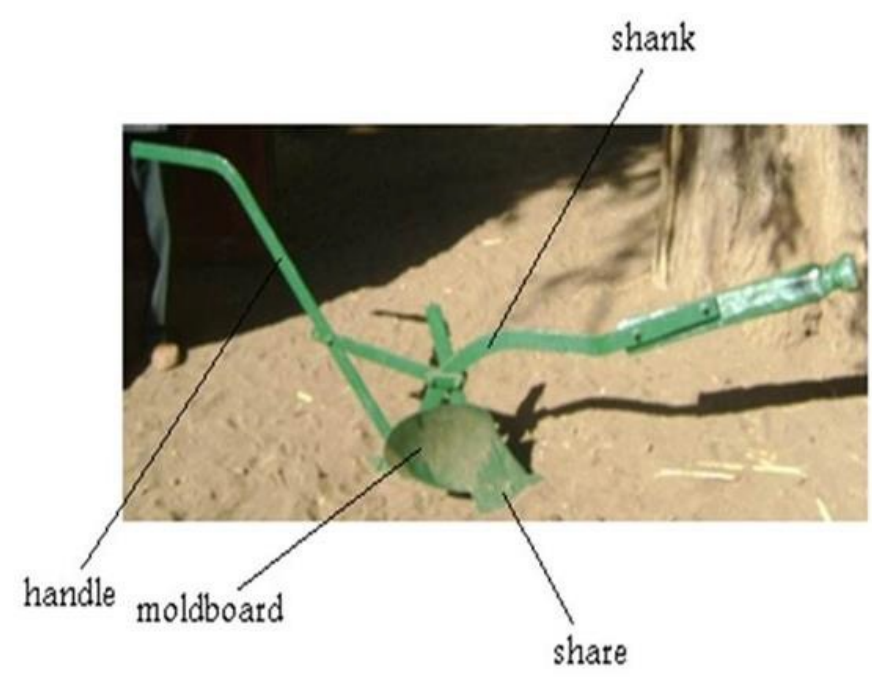

Source: Belal et al (2015)

Figure 3: Nuba hoe plough- Nuba Mountains

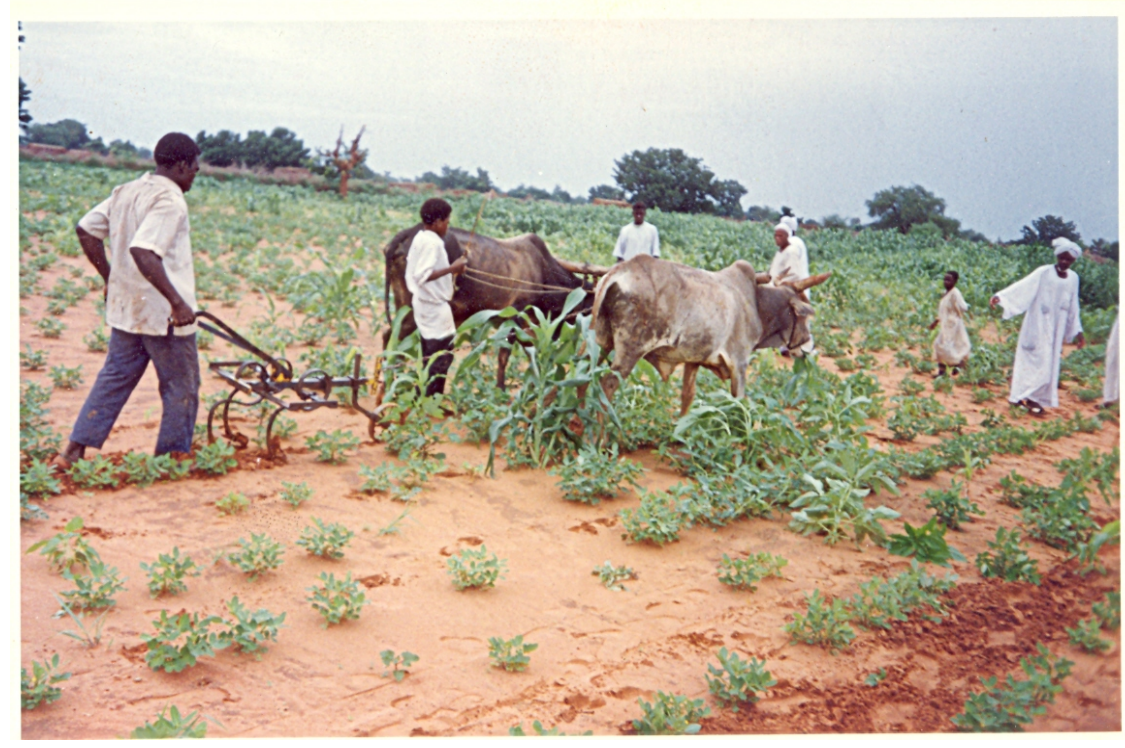

Source: Researcher's Camera 


\section{Figure 4: Groundnut liter- Nuba Mountains}

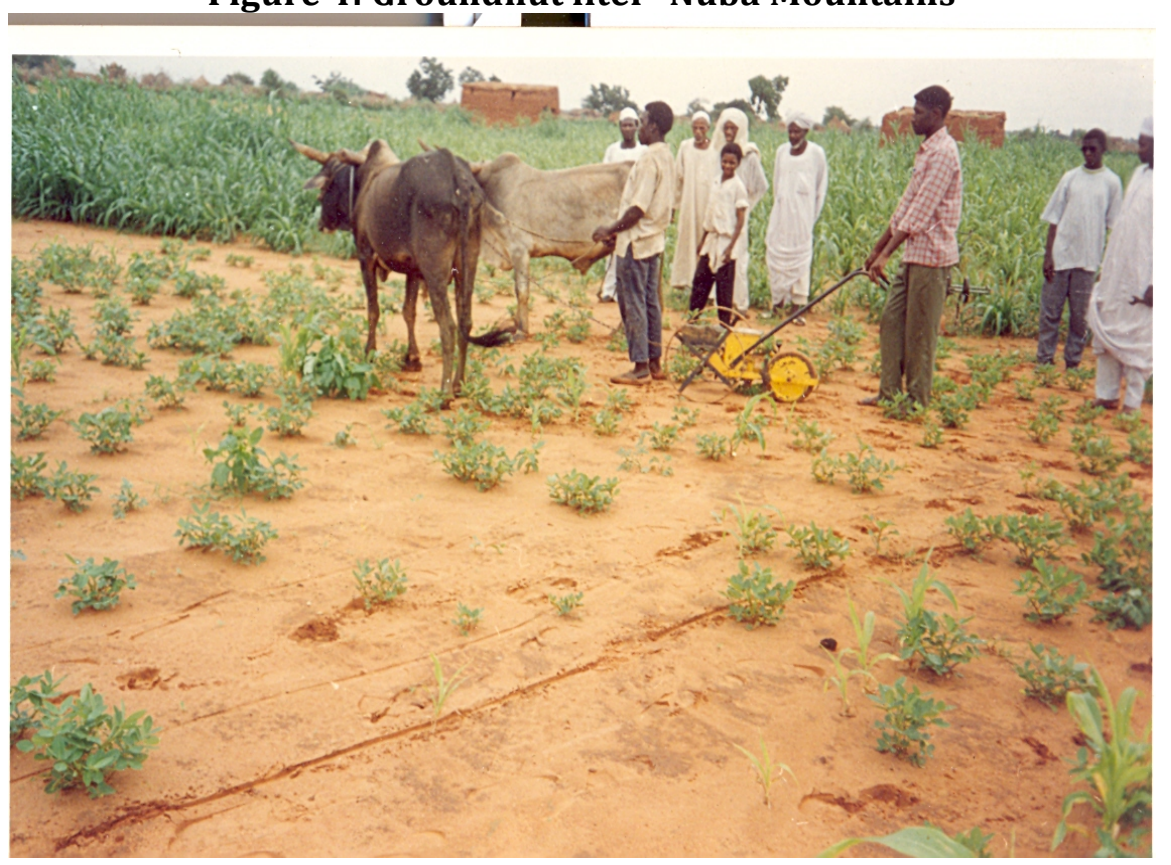

Source: Researcher's Camera

\section{CONCLUSION}

Animal traction as intermediate technology has been widely adopted in different staes of the Sudan, as an efficient, low-cost appropriate technology to increase agricultural productivity, and the cultivated area as well as to promote off-farm activities in the rural areas. Diffusion and adoption of this technology is recommended for food security, agriculture and sustainable development for the proposed region to: Secure food supply and to increase farmers' income through raising agricultural production and productivity; expand the cultivated area, reduce or eliminate labor bottleneck; improve timeless operations; save foreign exchange; provide jobs for some marginal groups (i.e. blacksmiths, landless groups, and others) and provide local transportation (i.e. animal carts), which also could be used as a source of income.

Selection of the Central Rain lands region based on the: Suitability of the physical environment for crop production as suitability and representivity of the different soil types, and satisfactory rain fall amounts; and availability of the prerequisites justifying the introduction of tested and used animal traction implements (i.e. availability of draught animals like oxen, camels and donkeys), based on the lessons learned from the past experience of rural development projects introduced in this region based on animal traction.

\section{References}

Ali, S (2012). Agricultural Extension Systems in Sudan. Available at http://www.scribd.com/doc/86784926/Agricultural-Extension-System-in-Sudanl.

Belal EA, Abdallah FE, Qishuo D, Abaker M, Talha Z. Role of animal traction in agricultural development in Zalingei area, Darfur-Sudan. Veterinaria 2015; 3(1): 22-27.

Bello AS, Mahmoud EM, Osman AM (2016). Identification of Factors that Affect Crop Productivity in the Traditional Rain-fed Sector of Sudan. N Y Sci J 2016; 9 (10), ISSN (1554-0200): 12-18.(online). http://www.sciencepub.net/newyork. 3. doi:10.7537/marsnys091016.03.-

Bello, A.S. (2014), “Agriculture Communal Labor in the Nuba Mountains”, J. Res. Peace Gend. Dev, Vol. 4 No. 3, pp. 48-54. 
Bello, A and Muneer, S (2008). Some Socio-economic and Environmental Impacts Of Animal traction as an Intermediate Technology In Rural Development: An Example from Sudan .J. Saudi Soc. for Agric. Sci., Vo. 7, No,2; 2008: 96-108.

Bello, A. (1998). Some Environmental and Socio-economic Impacts of Intermediate Technology in Rural Development. Ph.D. Thesis University of Khartoum.

El Siddig, E. (2003). The Acacia Senegal Agroforstry System in the Sudan. Unpublished paper.

FAO (2007). Draught Animal Power: An Overview. http://www.fao.org/ag/ags/agse/chapters1-e.htm.

FAO (1996). Special Program for Food Security (SPFS) Publications Division, Food And Agriculture Organization of the United Nation, viale delle Terme di Caracalla, 00100 Rome, Italy.

H. Kubkomawa, .U. Helen, F. Timon, M. Kabir and J. Neils (2011). The Use of Camels, Donkeys and Oxen for Post Emergence Weeding of Farm Lands in North-Eastern Nigeria. Journal of Agriculture and\& Social Sciences .ISSN 1813-2235;, 09-057/ZIP/2011/7-4-136-138.

HHoussou, N.; Kolavalli, H.;Bobobee, E., and Owusu V (2013). Animal Traction in Ghana. Working paper 34| June 2013. International Food Policy Research. Washington, DC 20006-1002 USA:15

Mahgoub, F (2014). Current Status of Agriculture and Future Challenges in Sudan.Nordiska Afrikainsinstitutet, Uppsala: 98.

Muneer, S. (1998). Dry Farming in Sudan: Low Inputs and Low Sustainability. A paper presented to the Workshop on Human Adaptation in East Africa Dry Land. Economic \& Social Institute, Khartoum: 15

Ouattara, K., Ouattara, B., Assa A., and Sédogo, M. P (2005). Long-term effect of plowing, and organic matter input on soil moisture characteristics of a Ferric Lixisol in Burkina Faso, Soil \& Tillage Research, Vol. 80 (1-2): 95-101.

Sanni, .A, Ogungbile, O. and Atala, K (2004). Interaction between livestock and crop farming in northern Nigeria, an integrated farming systems Approach. Nigerian J. Anim. Prod., 31: 94-99.

Schumacher., E., F., (1974). Small is Beautiful: Economic as if People Mettered. New York: Harper and Row Smillie, P (1991). Mastering the Machine. Poverty, Aid and Technology. Intermediate Technology Publications. London, WC/B4 HH, U.K.

Suleiman I., Salih, A., Bello, A., Bannaga, A., and Abelmagid, H (2008). Final Scoping Study- Sudan. Socio-Economic Development and Benefit Sharing Project (SDBS). Nile Basin Initiative, Entebbe, Uganda: 114.

UNDP(2012). Investing in Agriculture for Food Security and Economic Transformation.

WFP (2015). Food Security Update. At:

file://C:/Users/User/Desktop/Food\%20security\%20update\%20v\%202015.pdf.

WFP (2010). Emergency food security, blue Nile State-Sudan (Report): 58.

World Bank (1986).Poverty and Hunger: Issues and Options for Food Security in Developing Countries. Washington D.C., 1986 